\title{
The Status and the Role of 'Chocolate' Silicite in the Bohemian Neolithic
}

\author{
Pavel Burgert ${ }^{\mathrm{a}}$
}

\section{The author dedicates this article to the 8oth birthday of Prof. Ivan Pavli $\left({ }^{*} 1938\right)$}

\begin{abstract}
The article focuses on the chronological status of the distribution of 'chocolate' silicite originating from the area of south-east Poland in the prehistory of the Czech lands. The flow of 'chocolate' silicite across the Carpathian Mountains culminated in the period of the Stroke-Ornamented Ware culture $(5 \mathrm{roO} / 5000-4500 / 4400 \mathrm{cal} \mathrm{BC})$ in the area studied. Based on the analysis of the contexts of finds and the classification of the artefacts, the raw material is interpreted as an indicator of the presence of individuals or groups with an exclusive social status. Both the pattern of distribution and the status are common to other 'exotic' raw materials, especially for Carpathian obsidian, in the studied area in that same period. By comparing the spatial and chronological image expansion of both materials can lead to similar conclusions in their assessment.
\end{abstract}

KEY-WORDS: 'chocolate' silicite, distribution, chipped industry, social status, Stroked Pottery culture (SBK), obsidian, Eastern Bohemia

\section{INTRODUCTION}

'Chocolate' silicite is one of the most important lithic raw materials in the prehistory of the eastern part of Central Europe (Schild 197I, 1976; Borkowski et al., 2008; Werra et al., 2015). Its distribution range exceeds $500 \mathrm{~km}$ from sources (Fig. I) and it is thereby comparable to the distribution of Carpathian obsidian (Mateiciucová 2008; Biró 20I4; Burgert 20I5a: Fig. I). However, the catchment area is somewhat different due to the location of the resources above the Carpathian Arc. The purpose of this paper is to outline the specific role of 'chocolate' silicite, which results from its chronological and distributional position in the Neolithic period (Linear Pottery [Linearbandkeramik] Culture, hereinafter referred to as LBK: $5600-5000 / 4950 \mathrm{cal}$ BC, Stroke-Ornamented Ware culture [Stichbandkultur], hereinafter referred to as SBK: $5100 / 5000-4500 / 4400 \mathrm{cal} B C)$ in Bohemia (Fig. I and 2:A). The finds from the SBK period will be discussed more detail due to their larger number, therefore we can observe its presence in different types of localities.

\footnotetext{
${ }^{a}$ Institute of Archaeology of the CAS, Prague, Letenská 4, II8 or Prague I, Czech Republic; e-mail: burgert@arup.cas.cz; ORCID: 0000-0002-2032-0314
} 
$50 \mid$ Burgert

The recognition of this type of silicite, used as a raw material of prehistoric tools, was introduced into Bohemian research half a century ago by Slavomil Vencl (I971: 79). Nevertheless, not a lot of attention has been paid to it up to the present, and even in the basic syntheses devoted to the raw materials of the Neolithic lithic industries, no attention was paid to it (Popelka 1999; Sída 2006). The raw material was increasingly identified in the local sites due to research endeavours in Eastern Bohemia (Vávra I993: 2I8; Culáková 20I5; Burgert 20I5a: Tab. I).

\section{SPATIAL AND CHRONOLOGICAL DISTRIBUTION OF 'CHOCOLATE' SILICITE IN CZECH PREHISTORY}

The outcrops of 'chocolate' silicite are located in the northwest part of the Swiętokrzyskie (Holy-Cross) Mountains in the southeast Poland. They are located in a belt approximately $90 \mathrm{~km}$ long, oriented in a SE-NW direction, lying between the

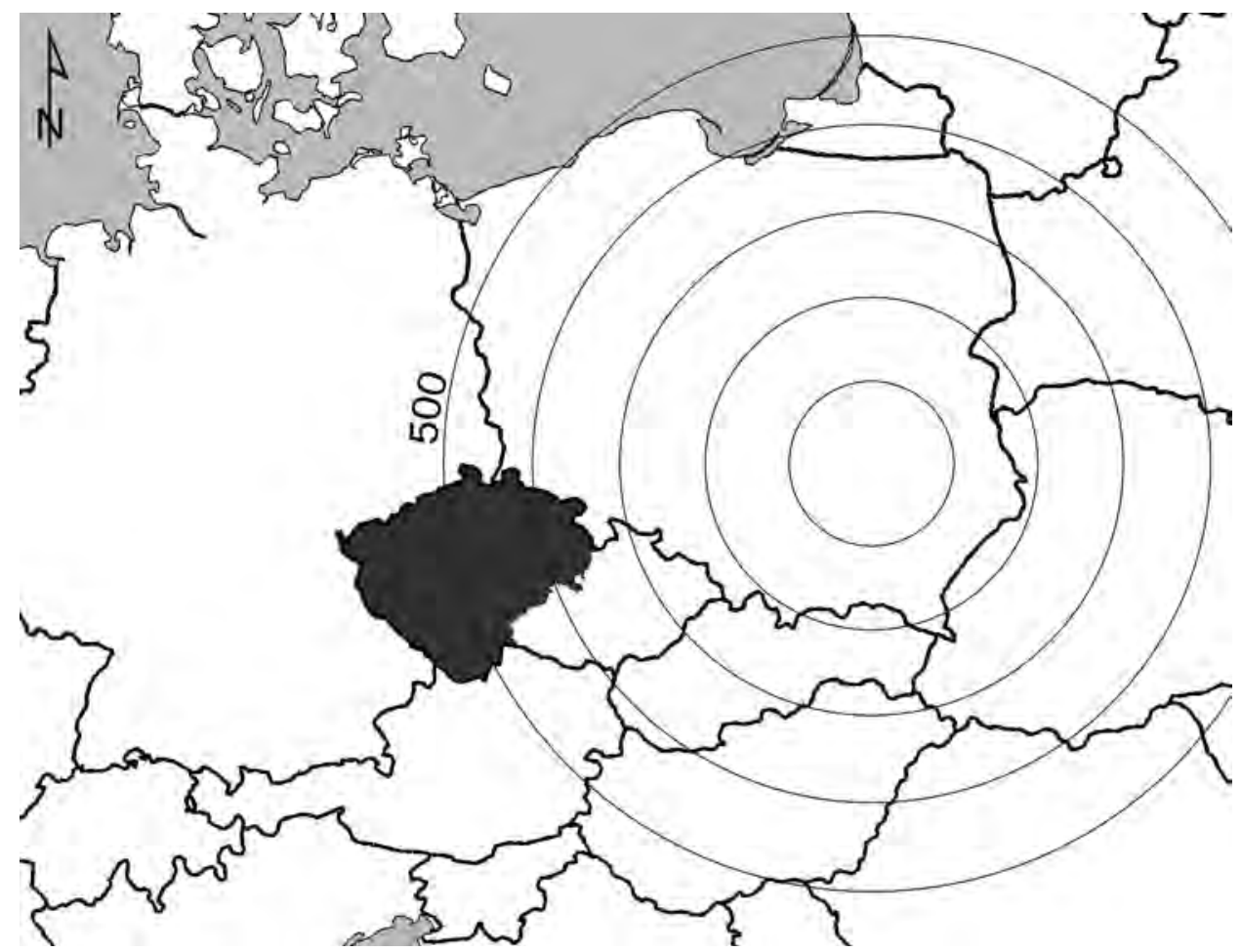

Fig. 1. Map of the eastern part of Central Europe with an indication of the area of interest - Bohemia (grey). The circles mark the distance from sources of 'chocolate' silicite at an interval of $100 \mathrm{~km}$. The radius of the smallest circle is $100 \mathrm{~km}$, of the largest $500 \mathrm{~km}$. Drawn: P. Burgert. 
valley of the Vistula at Zawichost in the east and the upper Radomka basin in the west. Around 25 sites with documented traces of prehistoric mining have been identified in this area (Balcer 1976; Budziszewski 2008: Ryc. I), usually in the form of vertical shafts. Neolithic mining activities are documented by a sequence of radiocarbon data (5500-4450 cal BC; Schild 1995; Schild et al., 1985; Budziszewski 2008: Table I). The distance from the source to the Bohemian localities is between 500 and $600 \mathrm{~km}$ as the crow flies (Fig. I).

All published or available finds of 'chocolate' silicite in Bohemia are summarised in Tab. I. It is obvious that this raw material was sporadically used already in the period of Upper Palaeolithic and in Mesolithic, but it rarely occurs in site assemblages of this period. The spatial dispersion of finds in these periods includes the entire area of Bohemia with a slightly increased concentration in the southern and eastern parts (Fig. 3: A). This, however, is probably to some extent because more attention of researchers

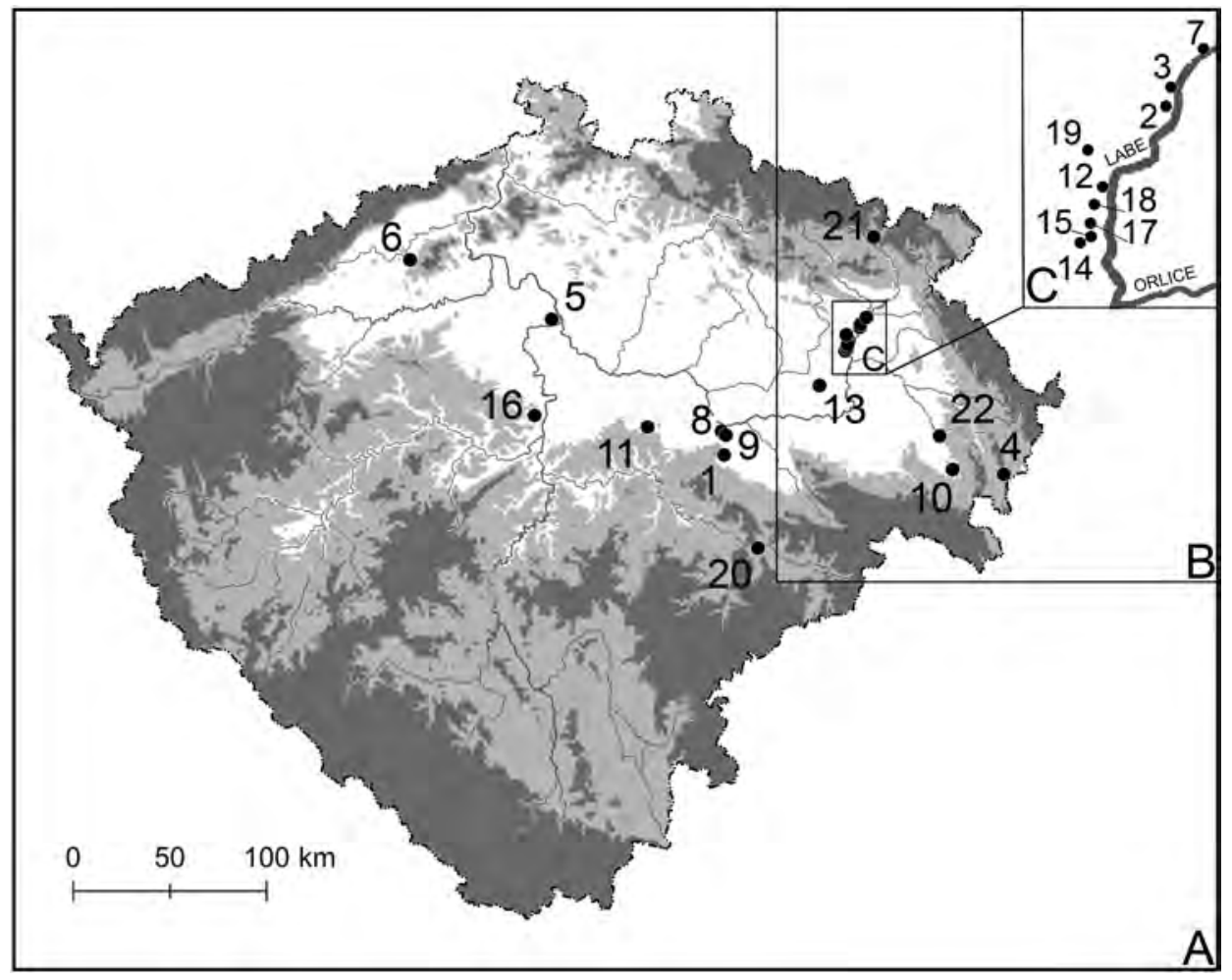

Fig. 2. The localisation of the finds of 'chocolate' silicite in Bohemia with the designation of individual area of interest. A: Bohemia; B: the eastern part of Bohemia; C: the area of the right bank of the Elbe River between Jaroměr and Hradec Králové. The numbering of sites corresponds to that in Table 1. Drawn: P. Burgert. 
$52 \mid$ Burgert

Table 1. Finds of 'chocolate' silicite in Bohemia. The numbering of the sites corresponds to that in Fig. 2.

\begin{tabular}{|c|c|c|c|c|c|c|}
\hline No. & Locality & Region & Quantity & Form & Chronology & Reference \\
\hline$[1]$ & [2] & {$[3]$} & {$[4]$} & [5] & {$[6]$} & [7] \\
\hline 1 & $\begin{array}{l}\text { Bylany, Kutná } \\
\text { Hora distr. }\end{array}$ & $\begin{array}{l}\text { Central } \\
\text { Bohemia } \\
\end{array}$ & 2 & & LBK II, III & $\begin{array}{l}\text { Lech } \\
\text { 1989: } 112\end{array}$ \\
\hline 2 & $\begin{array}{l}\text { Černožice 1, Hra- } \\
\text { dec Králové distr. }\end{array}$ & \begin{tabular}{|l|} 
Eastern \\
Bohemia
\end{tabular} & 1 & blade & NEOLITHIC & \\
\hline 3 & $\begin{array}{l}\text { Černožice 2, Hra- } \\
\text { dec Králové distr. }\end{array}$ & $\begin{array}{l}\text { Eastern } \\
\text { Bohemia }\end{array}$ & 3 & $\begin{array}{l}\text { sickle blade, } \\
\text { flakes }\end{array}$ & SBK IV & $\begin{array}{l}\text { Vávra } \\
\text { 1993: } 218\end{array}$ \\
\hline 4 & $\begin{array}{l}\text { Damníkov 1, Ústí } \\
\text { nad Orlicí distr. }\end{array}$ & \begin{tabular}{|l|} 
Eastern \\
Bohemia \\
\end{tabular} & 1 & & MESOLITHIC & $\begin{array}{l}\text { Čuláková } \\
\text { 2015: } 91\end{array}$ \\
\hline 5 & $\begin{array}{l}\text { Hořín u Mělníka, } \\
\text { Mělník distr. }\end{array}$ & $\begin{array}{l}\text { Central } \\
\text { Bohemia }\end{array}$ & 1 & & MESOLITHIC & $\begin{array}{l}\text { Přichystal } \\
\text { 2000: } 44\end{array}$ \\
\hline 6 & $\begin{array}{l}\text { Hrobčice, Teplice } \\
\text { distr. }\end{array}$ & $\begin{array}{l}\text { Northern } \\
\text { Bohemia }\end{array}$ & 1 & endscraper & SBK IV & \\
\hline 7 & $\begin{array}{l}\text { Jaroměř, Náchod } \\
\text { distr. }\end{array}$ & $\begin{array}{l}\text { Eastern } \\
\text { Bohemia }\end{array}$ & 40 & $\begin{array}{l}\text { blades, } \\
\text { sickle blade, } \\
\text { endscrapers }\end{array}$ & SBK IV & \\
\hline 8 & $\begin{array}{l}\text { Kolín I, Kolín } \\
\text { distr. }\end{array}$ & $\begin{array}{l}\text { Central } \\
\text { Bohemia }\end{array}$ & 5 & blades & SBK IV & \\
\hline 9 & $\begin{array}{l}\text { Kolín X, Kolín } \\
\text { distr. }\end{array}$ & \begin{tabular}{|l|} 
Central \\
Bohemia \\
\end{tabular} & 1 & flake & LBK III & \\
\hline 10 & $\begin{array}{l}\text { Kornice 2, Svitavy } \\
\text { distr. }\end{array}$ & \begin{tabular}{|l|} 
Eastern \\
Bohemia \\
\end{tabular} & 1 & & MESOLITHIC & $\begin{array}{l}\text { Čuláková } \\
\text { 2015: } 106\end{array}$ \\
\hline 11 & Krupá, Kolín distr. & $\begin{array}{l}\text { Central } \\
\text { Bohemia }\end{array}$ & 1 & flake & $\begin{array}{l}\text { UPPER PAL- } \\
\text { AEOLITHIC / } \\
\text { NEOLITHIC }\end{array}$ & \\
\hline 12 & $\begin{array}{l}\text { Lochenice, Hradec } \\
\text { Králové distr. }\end{array}$ & \begin{tabular}{|l|} 
Eastern \\
Bohemia \\
\end{tabular} & 1 & blade & NEOLITHIC & \\
\hline 13 & $\begin{array}{l}\text { Osice, Hradec } \\
\text { Králové distr. }\end{array}$ & $\begin{array}{l}\text { Eastern } \\
\text { Bohemia }\end{array}$ & 1 & $\begin{array}{l}\text { silicite (flint) } \\
\text { dagger }\end{array}$ & $\begin{array}{l}\text { EARLY } \\
\text { BRONZE } \\
\text { AGE }\end{array}$ & $\begin{array}{l}\text { Šebela and } \\
\text { Prichystal } \\
\text { 2014: } 75\end{array}$ \\
\hline 14 & $\begin{array}{l}\text { Plotiště nad } \\
\text { Labem - burial } \\
\text { ground, Hradec } \\
\text { Králové distr. } \\
\end{array}$ & $\begin{array}{l}\text { Eastern } \\
\text { Bohemia }\end{array}$ & 11 & $\begin{array}{l}\text { single } \\
\text { platform } \\
\text { core, blades, } \\
\text { arrowheads } \\
\end{array}$ & SBK IVb & \\
\hline 15 & $\begin{array}{l}\text { Plotišš̌ nad } \\
\text { Labem - site, Hra- } \\
\text { dec Králové distr. }\end{array}$ & $\begin{array}{l}\text { Eastern } \\
\text { Bohemia }\end{array}$ & 157 & $\begin{array}{l}\text { single } \\
\text { platform core, } \\
\text { cortical flakes, } \\
\text { blades, tools } \\
\end{array}$ & SBK IVb & \\
\hline 16 & $\begin{array}{l}\text { Praha - Velká } \\
\text { Chuchle, Praha } \\
\text { distr. } \\
\end{array}$ & $\begin{array}{l}\text { Central } \\
\text { Bohemia }\end{array}$ & 3 & arrowheads & $\begin{array}{l}\text { BELL- } \\
\text { BEAKER } \\
\text { CULTURE } \\
\end{array}$ & $\begin{array}{l}\text { Přichystal } \\
\text { and Sebela } \\
\text { 2009: } 684\end{array}$ \\
\hline
\end{tabular}




\begin{tabular}{|c|c|c|c|c|c|c|}
\hline [1] & {$[2]$} & [3] & [4] & [5] & {$[6]$} & [7] \\
\hline 17 & $\begin{array}{l}\text { Předměřice nad } \\
\text { Labem 1, Hradec } \\
\text { Králové distr. }\end{array}$ & $\begin{array}{l}\text { Eastern } \\
\text { Bohemia }\end{array}$ & 10 & $\begin{array}{l}\text { blades, flake } \\
\text { production }\end{array}$ & SBK IV & \\
\hline 18 & $\begin{array}{l}\text { Předměřice nad } \\
\text { Labem 2, Hradec } \\
\text { Králové distr. }\end{array}$ & $\begin{array}{l}\text { Eastern } \\
\text { Bohemia }\end{array}$ & 2 & blades & NEOLITHIC & \\
\hline 19 & $\begin{array}{l}\text { Smiřice, Hradec } \\
\text { Králové distr. }\end{array}$ & $\begin{array}{l}\text { Eastern } \\
\text { Bohemia }\end{array}$ & 8 & $\begin{array}{l}\text { endscrapers, } \\
\text { blades }\end{array}$ & SBK IV & $\begin{array}{l}\text { Burgert } \\
\text { 2015a: } \\
\text { Tab. } 1 \\
\end{array}$ \\
\hline 20 & $\begin{array}{l}\text { Světlá nad Sáza- } \\
\text { vou, Havlíčkův } \\
\text { Brod distr. }\end{array}$ & $\begin{array}{l}\text { Eastern } \\
\text { Bohemia }\end{array}$ & 1 & & $\begin{array}{l}\text { UPPER PAL- } \\
\text { AEOLITHIC }\end{array}$ & $\begin{array}{l}\text { Přichystal } \\
\text { 1998: } 357\end{array}$ \\
\hline 21 & $\begin{array}{l}\text { Voletiny, Trutnov } \\
\text { distr. }\end{array}$ & $\begin{array}{l}\text { Eastern } \\
\text { Bohemia }\end{array}$ & 2 & $\begin{array}{l}\text { endscraper, } \\
\text { burin }\end{array}$ & $\begin{array}{l}\text { UPPER PAL- } \\
\text { AEOLITHIC }\end{array}$ & $\begin{array}{l}\text { Vencl } \\
\text { 1978: } 10\end{array}$ \\
\hline 22 & $\begin{array}{l}\text { Zářecká Lhota 3, } \\
\text { Ústí nad Orlicí } \\
\text { distr. }\end{array}$ & $\begin{array}{l}\text { Eastern } \\
\text { Bohemia }\end{array}$ & 1 & & MESOLITHIC & $\begin{array}{l}\text { Čuláková } \\
\text { 2015: } 127\end{array}$ \\
\hline$\sum$ & Total & & 254 & & & \\
\hline
\end{tabular}

has been focused on these two areas in the past (Vencl et al., 2006; Čuláková 20I5). It should be noted, however, that the overall small amount of finds, regardless of the long period of time that these periods occupy, do not allow any closer conclusions.

The vast majority of other finds from Bohemia are concentrated in the Neolithic period. In the LBK period, however, the use of 'chocolate' flint in small quantities has so far been identified only in the lithic material from the extensive assemblage of finds from the settlement in Bylany near Kutná Hora (Kutná Hora district; Přichystal 1985; Lech 1989) and also recently in material from nearby Kolín (Kolín district; Fig. 3:B). All other Neolithic finds that we can closer classify come from the subsequent SBK period. Most of the finds from the SBK period are characterised by their noticeable concentration in a later phase of this culture, referred to as SBK IV (the classification of SBK here and elsewhere in the text is in accordance with the scheme by Marie Zápotocká 1998a).

Only two finds of 'chocolate' silicite are known from the post-Neolithic period in Bohemia. The first is a set of three arrowheads from the grave of the Bell Beaker culture in Central Bohemia. The other is a silicite dagger from the area of Eastern Bohemia. While it is a solitary find without a closer context, it can be typologically included in the period of the Early Bronze Age (Šebela and Přichystal 20I4: 75). These finds are referred to here only for the sake of completeness because they come from a completely different economic situation than the above-mentioned finds from earlier prehistory periods. 
$54 \mid$ Burgert
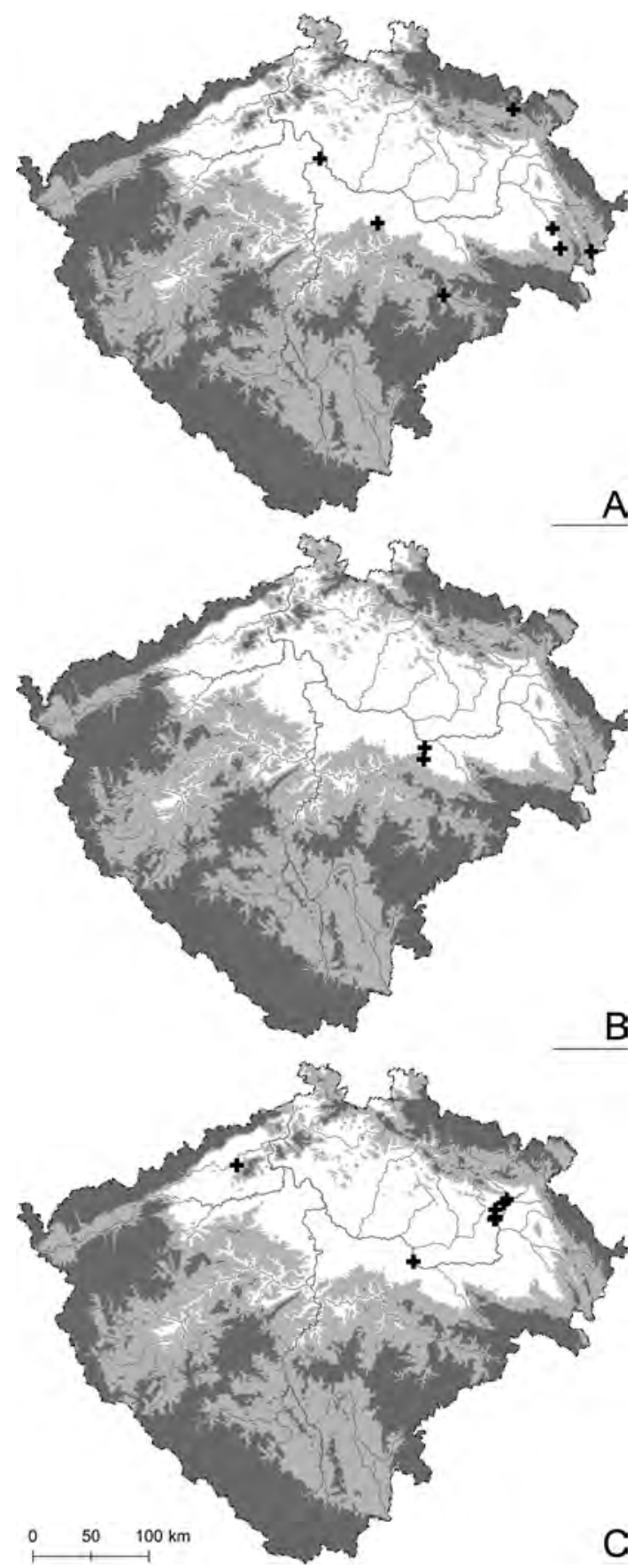

CONCENTRATION OF RAW MATERIAL IN EASTERN BOHEMIA

In terms of the spatial distribution of the finds of 'chocolate' silicite, it is obvious that their occurrence is concentrated in the eastern part of Bohemia (Fig. 2: B). This is, in general terms, a reflection of the relative closeness of this area to the location of the sources. What is striking, however, is the concentration of finds in a particular area of the right bank of the Elbe (Fig. 2: $\mathrm{C}$ and 3: C). This concerns only the later phase of SBK. Because of the exclusivity of this phenomenon, we will deal with it further.

In the area of the right bank of the Elbe in the section between today's towns of Jaromer (in the north, Náchod district) and Hradec Králové (in the south, Hradec Králové district) we can observe continuous settlement from the earliest Bohemian LBK (Pavlů and Vokolek 1996). The density of settlement culminates there in the period of the later SBK phase and it is the greatest in the entire region of Eastern Bohemia (Burgert 20I7). During this period, Circular Enclo-

Fig. 3. The spatial distribution of prehistoric findgs of 'chocolate' silicite in Bohemia. A: Upper Palaeolithic and Mesolithic; B: Linear Band Pottery;

C C: Stroked Pottery culture.

Drawn: P. Burgert. 


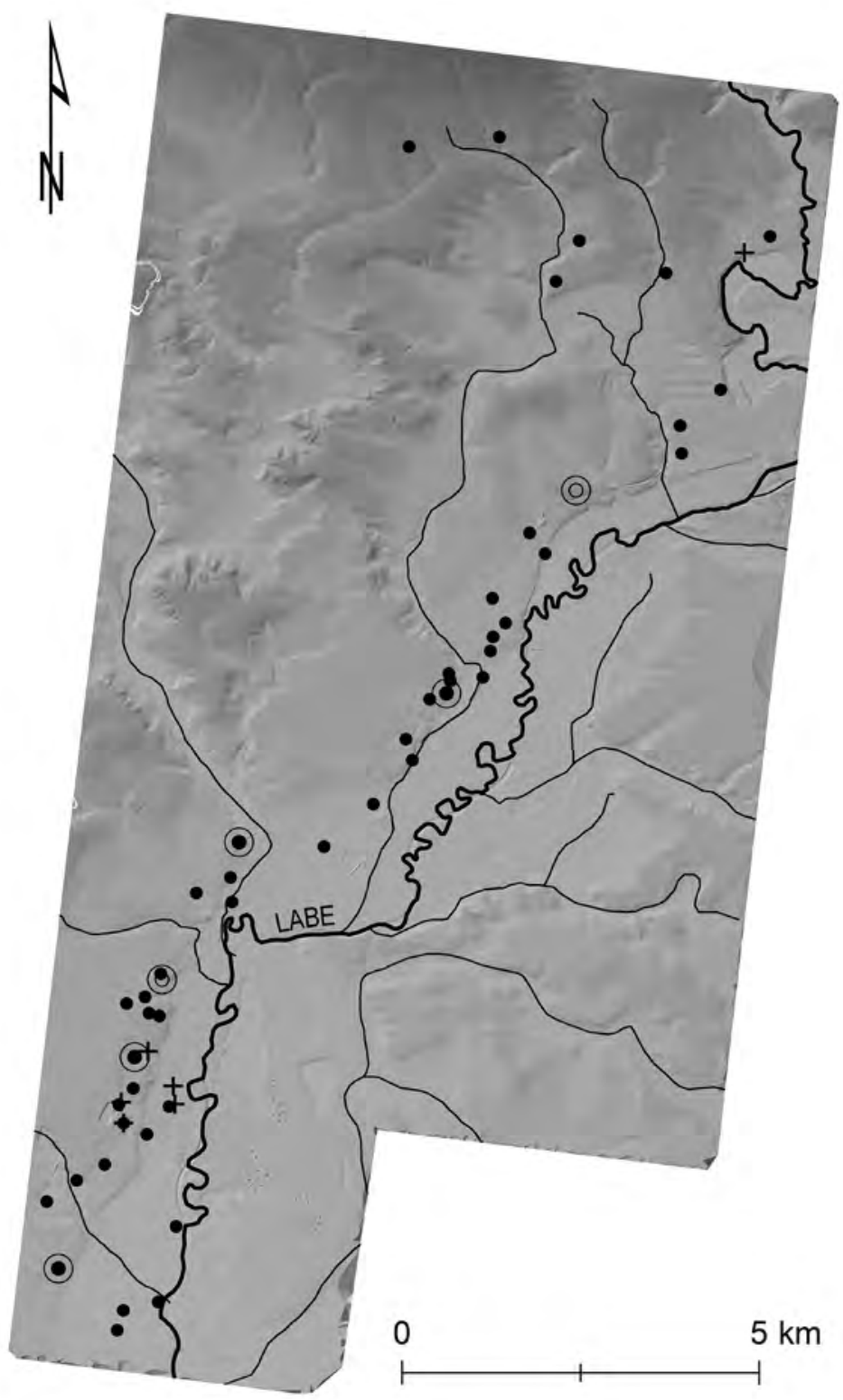

Fig. 4. Settlements at the right bank of the Elbe River in the section between Jaromerr and Hradec Králové (Hradec Králové and Náchod disrt., Eastern Bohemia, see Fig. 2: C) in the period of the late phase of Stroked Pottery culture (SBK IV). Dots: settlements; circles: Circular enclosures; crosses: graves or groups of graves. The Elbe River is reconstructed according to its situation in 1852.

Drawn: P. Burgert. 
$56 \mid$ Burgert
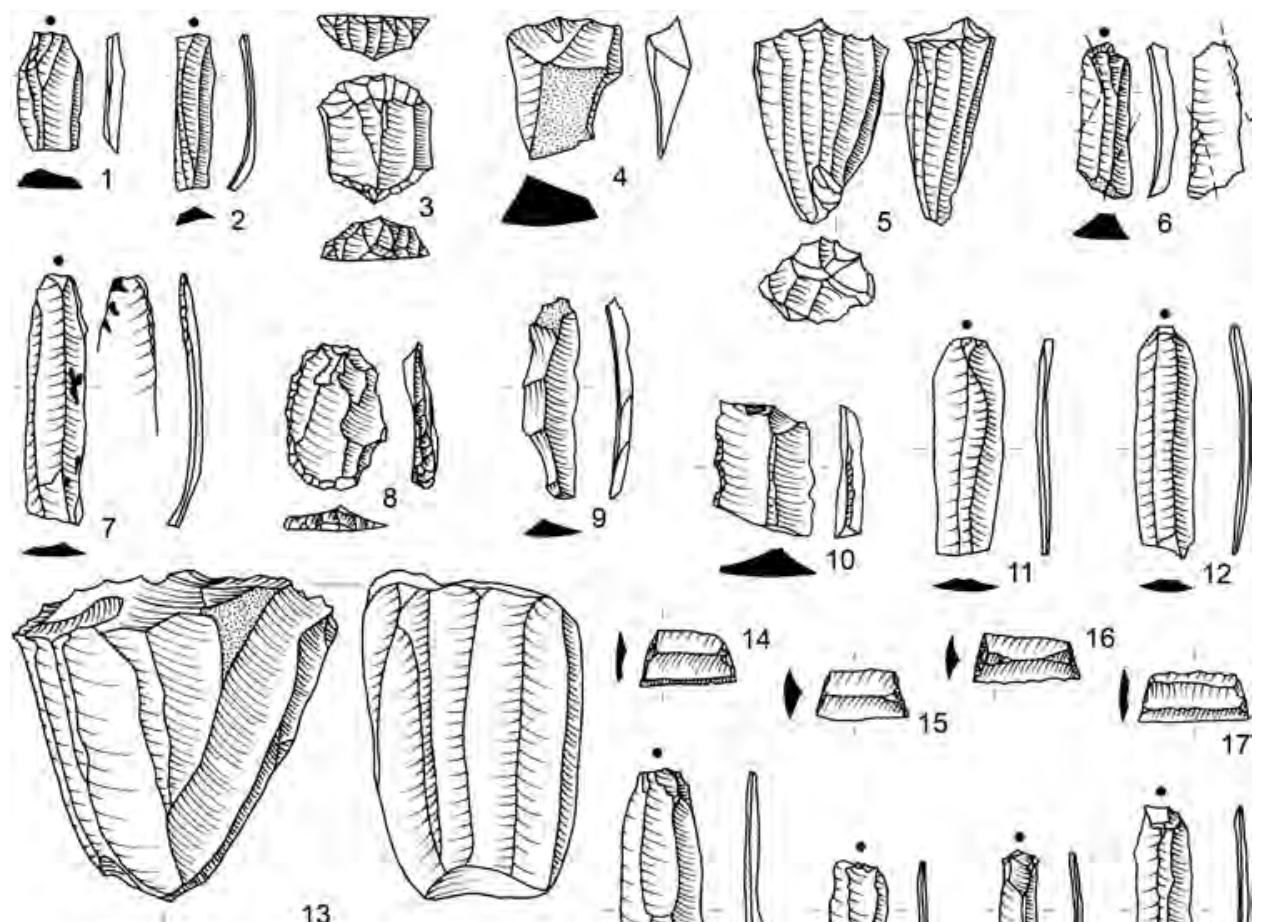

13
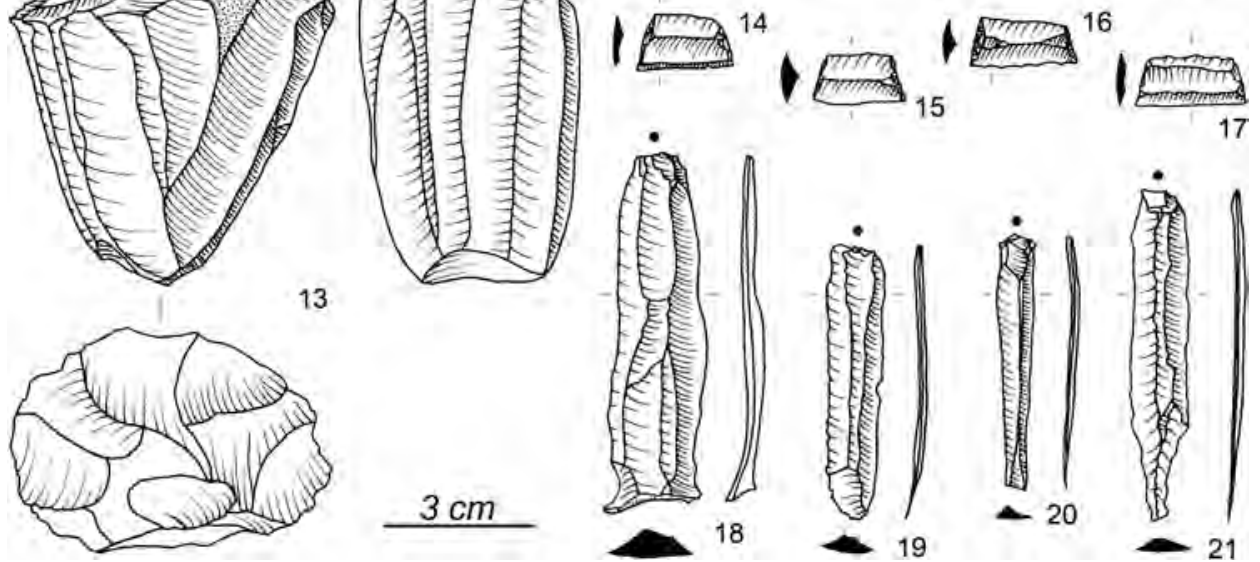

Fig. 5. Examples of 'chocolate' silicite finds from Bohemia. 1-5: Plotiště nad Labem, Hradec Králové distr., pit No. 74; 6: Jaroměř, Náchod distr.; 7: Kolín, Kolín distr. 8-10: Předměřice nad Labem, Hradec Králové distr.; 11-12: Plotiště nad Labem, Hradec Králové distr., child grave no. LVIII; 13-21: child grave no. LVII, weight of core: 223, 5 g. Drawn: P. Burgert and L. Raslová. 
sures, graves and groups of graves are concentrated exclusively in this part of Eastern Bohemia (Fig. 4). This is also where, during this period, we record a large concentration of 'chocolate' silicite finds.

Most of the finds in this area are tied to settlements. They therefore come from the standard contents of settlement pits. Their representation in settlement assemblages ${ }^{1}$ generally ranges up to $2 \%$. An exception is object No. 74 in Plotiště nad Labem, Hradec Králové district (a clay pit with the dimensions of $23 \times 13 \mathrm{~m}$ ). Its filling is surprisingly homogeneous in terms of the pottery, and it is possible to classify it to the end of the later phase of SBK (SBK IVb; Burgert 20I5a: 250). The chipped industry assemblage from this site comprises 1788 items with a relatively large share (8.8\%, I57 items) of 'chocolate' silicite. An important find is the fact that the 'chocolate' silicite assemblage includes evidence of the processing of this raw material on site (cores, technical and cortical flakes). This is the only documented workshop for processing this raw material in Bohemia. Based on the low representation of cortical flakes with a 100\% share of the cortex, it is evident that the partially pre-prepared cores were processed there.

Attention should also be paid to the presence of this raw material in graves. There are two rich children's graves, also from the Plotište nad Labem site (this burial ground is located next to the settlement; Zápotocká and Vokolek 1997; Burgert et al., 2016). In addition to necklaces made of the canine teeth of deer and the shells of gravel snails (Lithoglyphus naticoides) lithic items made of 'chocolate' silicite was also found there (Fig. 5). Its share represents 50\% (i.e., II items). Both children's graves are contemporary, which was proven on the basis of the refitting of the stone flakes from their contents; in one grave (LVII), a silicite core of glacial sediments was found, from which the blades found in the second grave had been chipped (grave LVIII; Vencl 1997: 32). Just like the workshop assemblage from feature No. 74 on the same site, the graves are also classified to the end of the later SBK phase (SBK IVb).

\section{DISTRIBUTION SCHEME}

As can be seen from Table I, 'chocolate' silicites occur in the lithic assemblages most often in the form of blades or final tools. This fact indicates a specific form of the distribution of this raw material. At present, we are aware of only two cores, both from the Plotiště nad Labem site. One comes from the already mentioned rich grave No. LVII (Fig. 5: 13), while the other one represents a part of the extensive assemblage

\footnotetext{
${ }^{1}$ As a representative example can be used an assemblage from the SBK settlement in Jaroměr (Burgert 20I5b). The local assemblage comprised 2015 items of chipped industry, originating from about 60 settlements features. The share of chocolate silicite in this characteristic settlement assemblage was $2 \%$ (Burgert 2017).
} 
$58 \mid$ Burgert

of lithics from feature No. 74 (Fig. 5: 5) in the adjacent settlement. It is likely that 'chocolate' silicite arrived in Bohemia in the form of prepared cores during the later phase of SBK. These were processed only in some settlements and only blades or tools were distributed further within the region.

\section{THE LINK BETWEEN THE RAW MATERIALS AND THE TOOLS AND SEMI-FINISHED PRODUCTS}

In terms of a potential link between 'chocolate' silicite and the type of tools and semifinished products, no specific fixed link was observed. This could be partly due to the relatively small number of these tools available for analysis. However, in terms of this raw material, we know both semi-finished products (blades) without any signs of use and the blades with sickle gloss that demonstrates their long-term use as working tools, specifically in sickles (Fig. 5: 6). We have also available endscrapers (Fig. 5: 3 and 8 ) and a simple burin from the pre-Neolithic period. A set of four trapezes that were probably used as arrowheads from grave no. LVII in Plotiště nad Labem (Fig. 5: I4-17) has no other parallels in the region.

Some artefacts bear traces of sickle gloss and residual mastic (Fig. 5: 6-7) that suggests an original attachment of the tool in a handle made of organic material. Similarly, these observations confirm the use of at least a part of 'chocolate' silicite artefacts for the same activities as other raw materials. This also does not exclude the possibility that in addition to prepared cores of the raw material, the ready-made tools with organic handles could also have been the subject of long-distance exchange.

\section{DISCUSSION}

The 'chocolate' silicite that is the subject of this study belongs in the category of 'exotic raw materials' in the Czech environment and generally also in the SBK environment. This term is used for stone material that comes from sources that are outside the actual cultural framework in which they were found. This definition applies in the case of SBK for both 'chocolate' silicite and for Carpathian obsidian, radiolarite and basically also for Bavarian Jurassic chert and other materials too. These raw materials were the subject of long-distance and inter-cultural exchange, although the mechanisms of their distribution between the individual different cultural environments are not exactly known. Due to the distances from the sources, which in the case of Bohemia the distance from the sources of 'chocolate' silicite and the obsidian are ca. $500 \mathrm{~km}$, it is considered unlikely that there was direct contact of the members of the local groups with natural outcrops. The most likely model is down-the-line exchange (Renfrew 
and Bahn 2000: 368), although, considering such a great distance, this model could be combined with others, especially in the areas immediately adjacent to the sources (the situation in which they initial distribution took place are unknown, for example we cannot know anything about the default conditions, such as the ownership rights of settled communities in relation to the sources).

A characteristic feature of exotic raw materials is the fact that they occur only in trace amounts in the total volume of stone tools. These raw materials therefore do not play a purely economic role, as is the case of the dominant raw materials in assemblages (in the case of the eastern part of the Bohemian SBK these are silicites from glacial sediments). Another typical feature of these raw materials is their recognisability due to their characteristic appearance. We will discuss this feature further below. It is therefore possible to assume that exotic raw materials played a specific role in the perception of prehistoric communities. Below, we will focus only on the period of the later SBK, in regard to which there are characteristic changes in the archaeological evidence. As we have already mentioned above, the finds of 'chocolate' silicite in Bohemia significantly concentrate in this period.

In the period of the later SBK phase (SBK IV), we encounter a significant phenomenon, the construction of circular enclosures (Bertemes and Meller 20I2). It is also possible to observe the gradual rise of the 'urbanisation' of settlements, including changes in the treatment of waste in settlements (Končelová and Květina 20I5; Burgert 20I5b). Rich children's graves appear in the funeral practices, though sporadically (Zápotocká 1998b: Taf. 67-68). All these changes can be explained by a major social transformation. The bearers of these changes could be individuals or groups of people with an exclusive social status. We believe that it is the presence of exotic raw materials in the assemblages that can be one of the indicators of the presence of these individuals or groups. This assertion is based on several assumptions:

I. The occurrence of exotic raw materials, including 'chocolate' silicite, is almost exclusively linked to the areas with strong contemporary settlements with the concentration of other phenomena, such as Circular Enclosures or groups of graves. The main region with these characteristics is the right bank of the Elbe in Eastern Bohemia (Fig. 4). The same conditions, however, also apply to the area of Kolín, where we also encounter concentration of settlements, accompanied by ringworks and grave finds (Fig. 3: C);

2. An increased concentration of 'chocolate' silicite was found in rich children's graves in Plotiště nad Labem (Fig. 5);

3. 'Chocolate' silicite is, like other exotic raw materials (obsidian, Bavarian Jurassic chert), a noticeable and well-identifiable raw material. This property is typical of status symbols (Hodder 1982); 
$60 \mid$ Burgert

4. The cores of 'chocolate' silicite in Bohemia were processed only at some settlements, on others we can encounter only the final products, or this raw material is absent;

The control and organisation of long-distance exchange mechanisms in archaic societies is demanding because it requires cross-border transfer of multiple settlement communities. At the same time, it requires the existence of an agent that has the ability to maintain exchange demands. This agent has the character of ritual social necessity and can be personified in the form of men whose exchange organization delivers social prestige (Strathern 1969, I971; Liep I99I; Ziegler 2012). Let us add that the monopolization of the long-distance exchange towards a narrow circle of powerful men is one of the basic mechanisms of the formation of social complexities (Terray 1974; Earle 1999).

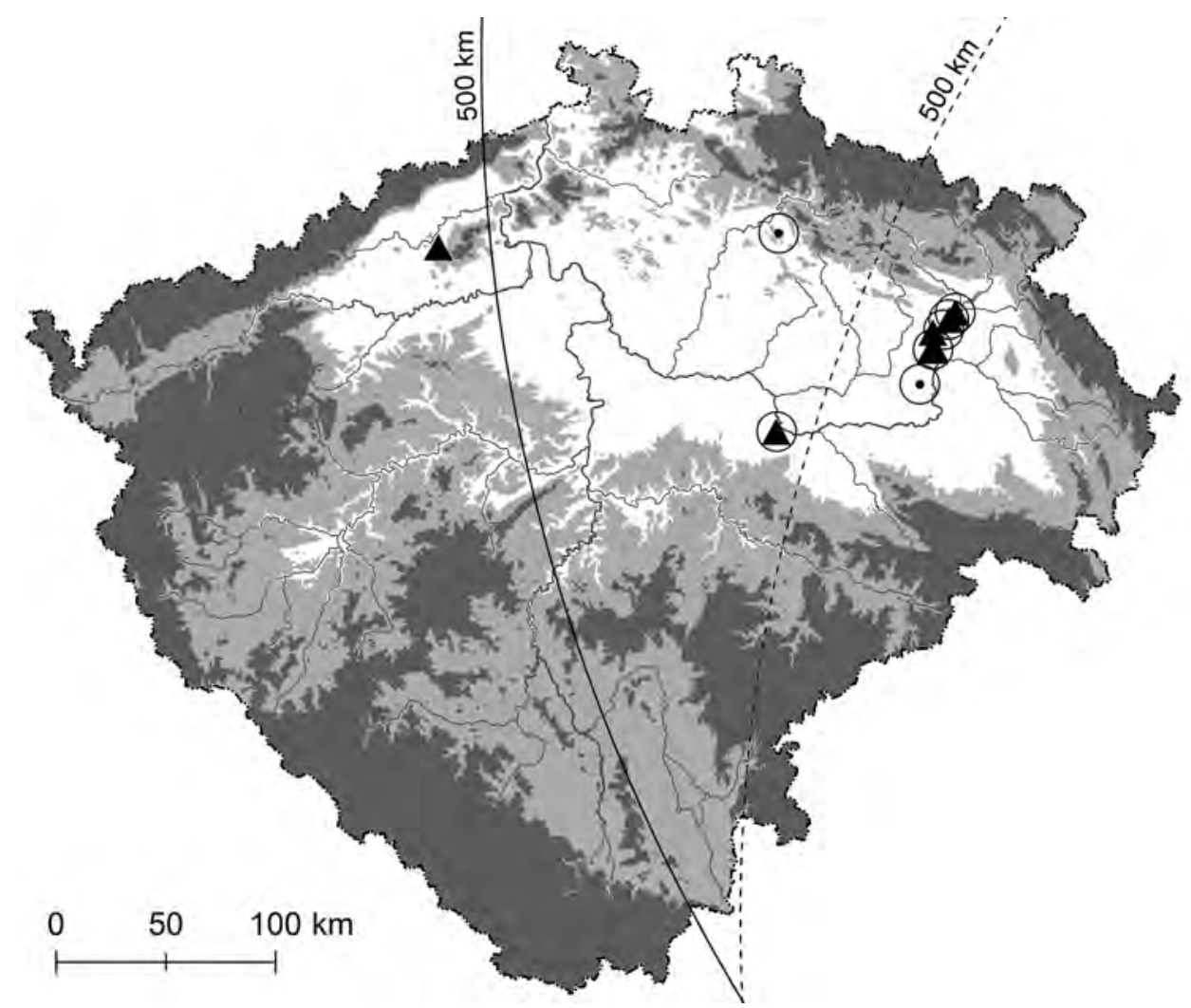

Fig. 6. Spatial distribution of finds of 'chocolate' silicite (triangles) and obsidian (circles) in the late phase of the stroked pottery culture (SBK IV). Continuous line circle: $500 \mathrm{~km}$ distance from 'chocolate' silicite sources; dotted line circle: $500 \mathrm{~km}$ distance from Carpathian obsidian sources.

Drawn: P. Burgert. 
We believe that on the basis of the facts mentioned above it is possible to assume that 'chocolate' silicite had an exceptional position within the framework of stone raw materials in the Late Neolithic environment in Bohemia, which excluded its purely utilitarian function. It is very likely that this raw material, and tools made from it, can be included in a group of status-enhancing symbols, which make it possible to identify the presence of individuals or groups of exceptional social status.

The status of 'chocolate' silicite defined in this manner can be compared to that of other exotic raw materials, especially Carpathian obsidian. The chronological and distributional position of both these raw materials in Czech prehistory seems to be identical (Burgert et al., 20I6). The occurrence of obsidian in Czech prehistory also culminates in the SBK IV period and its finds also concentrate in the area of Eastern Bohemia, specifically on the right bank of the Elbe (Fig. 6). This is also where the only two workshops in Bohemia are located in which the obsidian was chipped directly from its initial form of lump. The distance from the original sources is roughly the same for both materials and in Bohemia this is about $500 \mathrm{~km}$. As with 'chocolate' silicite, we expect a similar social status in terms of the Carpathian obsidian in Bohemia. We came to this conclusion on the basis of their fundamentally identical attributes (Burgert 2015a).

\section{CONCLUSION}

In Czech prehistory, 'chocolate' silicite is one of a number of types of objects of longdistance exchange, for which we use the term 'exotic raw materials'. Its occurrence in prehistoric assemblages can be observed there from the Late Palaeolithic/Mesolithic to the late Neolithic (Table I). Later finds (an arrowheads from grave of Bell Beaker culture and silicite dagger from the early Bronze Age) are extremely scarce. The distribution of this raw material culminates in the period of the later phase of the StrokeOrnamented Ware culture (SBK IV). During this period, the finds are concentrated in the area of Eastern Bohemia, namely in the area of the right bank of the Elbe River in the section between today's towns of Jaromer in the north and Hradec Králové in the south (Fig. 4). The share of this raw material in ordinary settlement complexes does not exceed two per cent and generally it is lower.

In the area of its greatest concentration, the finds of other exotic raw materials, especially obsidian, are also concentrated within the same time horizon. At the same time, we can observe a strong contemporary settlement density, accompanied by Circular Enclosures and groups of graves. This concerns both Eastern Bohemia and the area of Kolín, where there is also one minor accumulation of 'chocolate' silicite in the same period, in the later phase of SBK. 
$62 \mid$ Burgert

'Chocolate' silicite appears almost exclusively in the form of blades and tools in the settlement assemblages of lithic items. This fact suggests a specific form of distribution of this raw material. We currently know only one site in Bohemia where this raw material was processed in a workshop. This distribution scheme points to the specific social status of this raw material, which is also indicated by the presence of this raw material in grave finds.

\section{ACKNOWLEDGEMENTS}

This study was accomplished with support from the project 'Building Structures, Activity Areas and Site Layouts of the Late Neolithic Settlement Areas (5000/49004500/4400 BC)', No. 15-16963S, financed by the Czech Science Foundation (GAČR).

\section{REFERENCES}

Balcer, B. 1976. Position and Stratigraphy of Flint Deposits, Development of Exploitation and Importance of Świeciechów Flint in Prehistory. Archaeologica Carpathica 19: 179-199.

Bertemes, F. and Meller, H. (eds), 2004. Neolithische Kreisgrabenanlagen in Europa - Neolithic Circular Enclosures in Europe. Internationale Arbeitstagung vom 7. bis 9. Mai 2004 in Goseck. Halle, Tagungen des Landesmuseums für Vorgeschichte Halle.

Biró, K. T. 20I4. Carpathian Obsidians: State of Art. In M. Yamada and A. Ono (eds), Lithic raw material exploitation and circulation in Prehistory. A comparative perspective in diverse palaeoenvironments, 47-69. Liège, ERAUL I38.

Budziszewski, J. 2008. Stan badań nad występowaniem i pradziejową eksploatacją krzemieni czekoladowych. In: W. Borkowski, J. Libera, B. Sałacińska and S. Sałaciński (eds), Krzemień czekoladowy w pradziejach, 33-I06. Lublin-Warszawa, Studia nad gospodarką surowcami krzemiennymi w pradziejach 7 .

Burgert, P. 20I5a. Štípaná industrie z obsidiánu v Čechách. Archeologické rozhledy 67: 239-266.

Burgert, P. 20I5b. „Stabilitas loci“ of inhabitants of the Stroked Pottery site in Jaroměr. Anthropologie 53(3): 476-483.

Burgert, P. 2017. Struktura a chronologie sidlišt kultury s vypichanou keramikou ve východnich Čechách. Unpublished $\mathrm{PhD}$ thesis, Charles University in Prague.

Burgert, P., Vokolek, V. and Ř́dký, J. 20I6. Prostorová analýza a datace dvou ohrazení v sídelním areálu z mladšího neolitu v Plotištích nad Labem, okr. Hradec Králové. Archeologie ve středních Čechách 20: $925-933$.

Borkowski, W., Libera, J., Sałacińska, B. and Sałaciński, S. 2008 (eds), Krzemień czekoladowy w pradziejach. Studia nad gospodarką surowcami krzemiennymi w pradziejach 7. Warszawa - Lublin.

Čuláková, K. 20I5. Príspèvek k poznáni mezolitického osidleni Čech. Unpublished PhD thesis, Charles University in Prague.

Earle, T. 1999. Production and exchange in prehistory. In G. Barker (ed.), Companion encyclopedia of archaeology, 608-636. London, Routledge.

Hodder, I. 1982. Symbolic and structural archaeology. Cambridge. 
Končelová, M. and Květina, P. 20I5. Neolithic longhouse seen as a witness of cultural change in the postLBK. Anthropologie 53(3): 43I-446.

Lech, J. 1989. A Danubian raw material exchange network: a case study from Bylany. In J. Rulf (ed.), Bylany seminar 1987. Collected Papers, III-I20. Praha.

Liep, J. 1991. Great Man, Big Man, Chief: A Triangulation of the Massim. In M. Godelier, and M. Strathern (eds), Big men and great men. Personifications of power in Melanesia, 28-47. Cambridge, Cambridge University Press.

Pavlů, I. and Vokolek, V. 1996. The Neolithic Settlement at Holohlavy (Hradec Králové). Památky archeologické 87: 5-60.

Mateiciucová, I. 2008. Talking Stones: The Chipped Stone Industry in Lower Austria and Moravia and the Beginnings of the Neolithic in Central Europe (LBK), 5700-4900. Praha - Brno, Dissertationes Archaeologicae Brunenses/Pragensesque 4.

Popelka, M. 1999. K problematice štípané industrie v neolitu Čech. Praehistorica 24: 7-I22.

Přichystal, A. 1985. Štípaná industrie z neolitického sídliště v Bylanech (okr. Kutná Hora) z hlediska použitých surovin a jejich provenience. Archeologické rozhledy 37: 48I-488.

Přichystal, A. 1998. Kamenné suroviny z pozdně paleolitické lokality ve Světlé nad Sázavou. Archeologické rozhledy 50: 357-358.

Přichystal, A. 2000. Petrographische Bestimmung der Rohstoffe der gespaltenen Artefakte von der mesolit. Station in Hořín, Bez. Mělník. In K. Sklenář (ed.), Hořin III, 4I-45. Fontes Archaeologici Pragenses 24.

Přichystal, A. and Šebela, L. 2009. Př́íspěvek k poznání kamenné štípané industrie z pohřebiště kultury zvoncovitých pohárů v Praze - Velké Chuchli. Archeologie ve stréednich Čechách I3(2): 683-686.

Renfrew, C. and Bahn, P. 2000. Archaeology. Theories, Method and Practice. London.

Schild, R. I97I. Lokalizacja prahistorycznych punktów eksploatacji krzemienia „czekoladowego” na północno-wschodnim obrzeżeniu Gór Świętokrzyskich. Folia Quaternaria 39: I-60.

Schild, R. 1976. Flint mining and trade in polish prehistory as seen from the perspective of chocolate flint of central Poland. A second approach. Acta Archaeologica Carpathica I6: I47-177.

Schild, R. 1995. Tomaszów I, Radom Province. Archaeologia Polona 33: 480-488.

Schild, R., Królik, H. and Marczak, M. 1985. Kopalnia krzemienia czekoladowego w Tomaszowie. Wrocław - Warszawa - Kraków - Gdańsk - Łódź.

Strathern, A. 1969. Finance nad production: Two strategies in New Guinea Highlands exchange systems. Oceania 40(I): 42-67. doi:I0.1002/j.1834-446I.1969.tboio56.x.

Strathern, A. 197I. The rope of moka. Big-men and ceremonial exchange in Mount Hagen, New Guinea. Cambridge, Cambridge University Press. Cambridge studies in social anthropology 4.

Šebela, L. and Přichystal, A. 20I4. Silicitové dýky na území České a Slovenské republiky. Předběžná studie. Studia Archaeologica Brunensia 19: 67-94.

Šída, P. 2006. Distribuční areály surovin v neolitu na území České republiky. Archeologické rozhledy 58 : 407-426.

Terray, E. 1974. Long-distance exchange and the formation of the State: the case of the Abron kingdom of Gyaman. Economy and Society 3(3): 315-345. doi:10.1080/03085147400000016.

Vávra, M. 1993. Neolitická plastika z Černožic. Archeologické rozhledy 45: 212-220.

Vencl, S. 197I. Současný stav poznání postmesolitických štípaných industrií v Československu. In: J. K. Kozłowski (ed.), Z badań nad krzemieniarstwem neolitycznym i eneolitycznym, 74-99. Kraków.

Vencl, S. 1978. Voletiny - nová pozdně paleolitická industrie z Čech. Památky archeologické 69: I-44.

Vencl, S. 1997. Bemerkungen zur Steinindustrie. In V. Vokolek and M. Zápotocká, Neolithische Gräber und Gräberfelder in Plotiště n. L. und Předmérice n. L., Bezirk Hradec Králové, 5-55. Památky archeologické 88 . 
$64 \mid$ Burgert

Vencl, S. (ed.) 2006. Nejstarši osídleni jižnich Čech. Praha.

Werra, D. H., Siuda, R., Grafka, O. and Segit, T. 2015. Pierwsze próby charakterystyki geochemicznej i palinologicznej krzemienia „czekoladowego” z kopalni Wierzbica „Zele”, pow. Radom. Acta Universitatis Nicolai Copernici, Archeologia 34: 249-270.

Zápotocká, M. 1998a. Die chronologische und geographische Gliederung der postlinearkeramischen Kulturgruppen mit Stichverzierung. In J. Preuss (ed.), Das Neolithikum in Mitteleuropa. Kulturen - Wirtschaft - Umwelt vom 6. bis 3. Jahrtausend v. u. Z. Band I/2, 286-306. Weissbach, Beier \& Beran.

Zápotocká, M. 1998b. Bestattungsritus des Böhmischen Neolithikums (5500-4200 B.C). Gräber und Bestattungen der Kultur mit Linear-, Stichband-und Lengyelkeramik. Praha.

Zápotocká, M. and Vokolek, V. 1997. Die neolithische Gräber und Gräberfeld in Plotiště N. L. und Předměřice n. L., Bezirk Hradec Králové. Památky archeologické 88: 5-55.

Ziegler, R. 2012. The Kula Ring of Bronislaw Malinowski: Co-evolution of an Economic and Ceremonial Exchange System. Review of European Studies 4(I): 15-27. 